\title{
Abdominal Aorta
}

National Cancer Institute

\section{Source}

National Cancer Institute. Abdominal Aorta. NCI Thesaurus. Code C32038.

The portion of the descending aorta that lies within the abdomen, beginning below the diaphragm and ending at its division into the right and left common iliac arteries. 